\title{
International cooperation in food security in Uzbekistan
}

\author{
Nurmatov Abdujabbor Ne'matjonovich ${ }^{\mathbf{1}}$ \\ ${ }^{1}$ Doctoral candidate at the Institute of History of the Academy of Sciences of the Republic of \\ Uzbekistan \\ Email: nurmatov_a@umail.uz
}

\begin{abstract}
The article covers the issues of ensuring food security, reforms carried out by Uzbekistan in this regard and mutual cooperation, which are becoming one of the most pressing problems in the world today. The increase in the number of Population year-on-year, climatic changes, urbanization, economic, ecological factors adversely affect the volume and quality of food production. This, in turn, dictates the implementation of deep consistent reforms in the spheres of existing rural agriculture and food industry. In recent years, with the aim of accelerating the development of agricultural production and the food industry, addressing sectoral challenges, Uzbekistan has been working not only in domestic capacity but also with international organizations and developed countries. In particular, Uzbekistan joined the Food and Agriculture Organization (FAOUN) on 2 November 2001. During this period, Uzbekistan has implemented a number of national and regional projects in collaboration with the UN. For example, Uzbekistan carried out 8 national and regional projects in the Republic during 2001-2015 in cooperation with this organization. On June 5-6, 2014 in Tashkent on the initiative of Uzbekistan held an international conference on the theme "significant reserves of Food Program Implementation in Uzbekistan". In addition, the FAOUN's 32nd regional conference for Europe is scheduled to be held in Uzbekistan for the first time among the countries of Central Asia on May 5-7, 2020. This is evidenced by the growing strengthening of cooperation with the FAOUN Organization of Uzbekistan.
\end{abstract}

Keywords: food security, agriculture, food industry, cooperation, FAOUN, aeroponics, investment, MDG (Millennium Development Goals), material and technical base.

\section{INTRODUCTION}

In the history of mankind, the food problem has been and continues to be relevant worldwide for a variety of reasons. Continuous population growth, climate change, water scarcity, natural disasters, urbanization, economic and environmental crises, in turn, have a negative impact on the size and quality of food production. That is why, taking into account such problems internationally, much emphasis is placed on accelerated development of agriculture and food security. In particular, the Food and Agriculture Organization of the United Nations (FAOUN) is strengthening its cooperation with many countries in the development of agriculture and food industry.

2014 year by the FAOUN "International Year of family farming " [1. The B. 101] and the fact that 7 June was declared the "WorldWide Food Safety Day"[2] also means that this issue is one of the important issues that should be paid special attention on a global scale.

Domestic capacity plays a major role in ensuring food security. However, the rapid population growth has led to the need for new housing at the expense of arable land. In particular, the average irrigated agricultural land in Uzbekistan was 0.20 hectares in 1990, 0.15 hectares in 2010, and by 2030 the population will grow by 0.12 hectares [3. B. 102] the area is expected to fit.

This leads to an annual complication of food production, especially in the regions of the Ferghana Valley, which are inhabited by regions of the republic. For example, at the end of 2017, the population of $1 \mathrm{~km}^{2}$ in the Republic of Uzbekistan was 72.7 people. [4. B. 25]. Naturally, this will increase even more due to population growth.

This calls for deeper reforms in the existing agricultural and food industries. In this regard, a lot has been done in the country during this period. As a result, a number of achievements have been made in 
these areas. To date, more than 170 varieties of vegetables, melons and potatoes, fruit and berry crops and grapes have been created in Uzbekistan [5]. Despite the fact that Uzbekistan has great potential for agricultural production, there are important issues to consider.

For example, at present Uzbekistan is one of the countries that imports potatoes. Exports from the importer of potatoes may be included in the list of exporting countries if they take into account the natural climate and the conditions of the country, and in the most efficient way possible. That is why special attention has been paid to this issue and a number of practical steps have been taken. In particular, the implementation of the EU-funded Sustainable Rural Development Program in Uzbekistan aims to address these problems and, in February 2018, 19.5 tons of 7 varieties of potatoes were imported from France and tested in Andijan region. [6]. Productivity is higher than in France, and the yield is twice a year. It can be seen that potato cultivation, along with many agricultural products in Uzbekistan, is very promising.

As a result of the research carried out over the past years, a new method of seed cultivation in the aeroponics ${ }^{1}$ method in the Namangan region was introduced in practice[7]. This method makes it possible to obtain a yield up to 6 times higher than the traditional method. Therefore, special programs on potato seed production and supply of high quality seeds throughout the Republic were developed based on this experience. Of course, support for this project will lead to a decrease in consumption and seed potatoes in the country due to the high cost of foreign countries, and such successes will contribute to ensuring food security in the country.

Given that food security is becoming more urgent every day, it requires constant development of industries. Therefore, Uzbekistan has established cooperation with many developed countries and international organizations in order to widely introduce intensive production methods, introduce scientific achievements into production, equip the material and technical base of agricultural and food industry enterprises with modern equipment and technologies.

In particular, Uzbekistan is strengthening cooperation with the Food and Agriculture Organization of the United Nations (FAOUN), which is currently developing extensive cooperation with many countries in the field of food production and food security.

In order to further develop agricultural production and ensure food security, Uzbekistan became a member of FAOUN on November 2, 2001[8]. [B. 47]. In 2014, an official FAO office was established in Uzbekistan [9]. This, in turn, has helped to raise these partnerships to a new level. Uzbekistan during 2001-2015, 8 national and regional projects were implemented in the Republic together with this organization. In particular, on June 5-6, 2014, at the initiative of Uzbekistan, an international conference on "Important Resources for the Food Program in Uzbekistan" was held in Tashkent [10]. It was attended by more than 200 people from 40 countries and 20 international organizations. At the conference, Uzbekistan's favorable conditions for food security and practical activities in this area were highlighted by Jose Gratziano da Silva, Director General of the organization. In the following years, a number of important national and regional projects have been implemented in cooperation with the FAOUN of Uzbekistan. In particular, the FAO initiated 32 regional conferences for Europe in Uzbekistan at the FAO Regional Ministerial Conference held in Rome, Italy in June 2019, and supported by the ministers of Agriculture of 51 European and Asian countries [11]. This regional conference will be held in Uzbekistan for the first time among the countries of Central Asia on May 5-7, 2020.

On August 28, 2014, FAOUN signed the FAOUN Partnership Framework for Uzbekistan [12. B. 65]. The directions of assistance provided by the FAO to Uzbekistan can be seen in the following:

- production of high value agricultural products for domestic and export markets through crop diversification and improved producing;

- Introduction of effective pest management systems and systems, implementation of agriculture that promotes environmental protection

- Strengthening the productivity of livestock and poultry, prevention of diseases of livestock and the development of beekeeping.

- Development of national fisheries, increase of their productivity

\footnotetext{
${ }^{1}$ Note. Aeroponics is a process in which you produce soil without any soil or substrate. At the same time, the roots of the plant hang in the air, not in the soil. Nutrients are sprayed onto them in the form of aerosols. This method saves water and energy and maintains plant health.
} 
- Effective management of natural resources, development of forestry, increase of incomes in rural areas, use of cost-effective, advanced technologies in management of land and water resources and prevention of risks associated with drought.

As a result of the work carried out over the past years, a sharp decrease in the volume of production and import in Uzbekistan itself of a large number of products necessary for consumption by the population has been achieved. So, if the share of food in the total import of the republic in 1990 amounted to 48.9 percent, then in 2000 it was 12.3 percent, then by 2018 it was 8.1 percent [13]. B. 49. 245], while the export of many agricultural products increased.

The reforms carried out by Uzbekistan in this direction and a worthy contribution to the food supply of foreign countries through the export of agricultural products were recognized by the international community and recognized in 2015 as one of the 14 states that achieved the MDGs (Millennium Development Goals) for achievements in ensuring food security in Uzbekistan [14].

It can also be seen that Uzbekistan is growing in the international ranking of food security from year to year. In particular, according to a study conducted by the American research Center The Economist Intelligence Unit, in itself, that Uzbekistan ranked 64th[15] in the overall rating of food security above the previous rating by 9 points and is a practical result of the country's reforms in this direction.

\section{CONCLUSION}

In conclusion, we can say that over the past years, Uzbekistan has accomplished a number of positive steps in agricultural development and food security. However, given the fact that food security is a global problem today, the following recommendations can be made to ensure the sustainable development of this sector:

- To expand the practice of intensive land use (for example, drip irrigation should be expanded, since irrigation reduces water consumption more effectively than conventional methods, and positively affects productivity)

- further strengthening of international links in the agricultural, food and other sectors, and attracting foreign investment

- development of domestic production of imported food products (in particular, in order to increase the volume of production of meat products, it is necessary to expand the area of food crops)

- Strengthening the implementation of scientific achievements in production

- Modernization and expansion of material and technical base of agricultural and food industry enterprises in accordance with modern requirements

- development and popularization of scientific recommendations on agro technical and other issues of land use

- Expansion of branches of higher education in the developed countries, including agriculture, food industry and veterinary science in Uzbekistan, particularly in the Ferghana Valley.

\section{REFERENCES}

1. Archive of the Presidential Administration of the Republic of Uzbekistan. Stock 2048, List 30, Volume 38, Volume 101.

2. https://undocs.org/ru/A/RES/73/250

3. Archive of the Presidential Administration of the Republic of Uzbekistan. 2048 Stock, List 30, Volume 38, Volume 102

4. Social Development and Living Standards in Uzbekistan. 2014 - 2017. -T. 2018, -B. 25.

5. https://www.gov.uz/uz/news/view/1522

6. http://www.xs.uz/uzkr/post/ozbekiston-qachon-kartoshkani-import-qiluvchi-davlatdan-eksportqiluvchi-mamlakatga-ajlanadi

7. https://president.uz/uz/lists/view/1689

8. http://www.lex.uz/ru/docs/2502790 
9. http://uza.uz/oz/business/zbekistonda-2020-yil-faoning-32-ududiy-konferentsiyasi-tkazi-23-062019; http://agro.uz/uz/news/agro/2020-yil-5-7-may-kunlari-zbekistonda-faoning-32-ududiykonferentsiyasi-tkaziladi/

10. Abdimuminov O. Uzbekistan's participation in the UN specialized agencies and programs // Public opinion human rights. No. 1. 2018. -B. 65.

11. Main trends and indicators of economic and social development of the Republic of Uzbekistan during the years of independence (1990-2011) and forecasts for 2012-2015. - T .: Uzbekistan, 2013. - B. 49; Socio-economic situation in the Republic of Uzbekistan. January-December 2018. -T. 2019. -B. 245.

12. https://mfa.uz/uz/press/news/2016/06/7618/

13. http://uza.uz/oz/society/ozi-ov-at-khavfsizligini-taminlashda-khorizhiy-tazhriba-01-062018? month=06\&year=2018\&ELEMENT_CODE=ozi-ov-at-khavfsizligini-taminlashdakhorizhiy-tazhriba-01-06-2018\&SECTION_CODE=society 